\title{
KRITIK DIRI SEBAGAI MEDIATOR PADA HUBUNGAN KONSEP DIRI DAN PERILAKU NONSUICIDAL SELF-INJURY REMAJA KORBAN PERUNDUNGAN
}

\author{
Inca Agustina Arifin ${ }^{1}$, Naomi Soetikno ${ }^{2}$, Fransisca Iriani R. Dewi ${ }^{3}$ \\ ${ }^{1}$ Magister Psikologi, Universitas Tarumanagara Jakarta \\ Email: inca.arifin@gmail.com \\ ${ }^{2}$ Fakultas Psikologi, Universitas Tarumanagara Jakarta \\ Email: naomis@fpsi.untar.ac.id \\ ${ }^{3}$ Fakultas Psikologi, Universitas Tarumanagara Jakarta \\ Email: fransiscar@fpsi.untar.ac.id
}

Masuk : 30-11-2020, revisi: 01-05-2021, diterima untuk diterbitkan :01-05-2021

\begin{abstract}
Nonsuicidal self-injury (NSSI) is a self-destructive action concerning direct and deliberate destruction to one's own body tissue without suicide intent. Previous studies have found that NSSI is commonly widespread among adolescents and strongly linked to bullying victimization. However, fewer studies explain cognitive process behind NSSI behaviours of bullying victims. The objective of this study is to examine the mediating role of self-criticism between self-concept and nonsuicidal self-injury behaviours in bullying victim adolescents. The research design is a descriptive quantitative ex-post facto research in non-experimental form. The participants of this study are adolescents between the age of 12-21 and victims of bullying $(n=68)$. The sampling technique used in this study is convenience non probability sampling. The instrument used in this study are Tennessee Self Concept Scale (TSCS) for measuring self concept; Forms of Self-Criticising/Attacking \& Self Reassuring Scale (FSCRS) for measuring self-criticism; and Inventory of Statement About Self Injury (ISAS) for measuring NSSI behaviours. This study uses linear regression analysis. The result shows that self-criticism is a perfect mediator in the association between self-concept and nonsuicidal self-injury in bullying victim adolescents. This study also shows that self-concept negatively correlates with self-criticism and NSSI behaviours. That means, the more positive one's self-concept, he/she would have lower self-criticism and lower possibility in conducting NSSI behaviours. These results are useful in understanding the thinking process in NSSI actions, also in determining more effective prevention that focus in developing self-concept and lowering self-criticism.
\end{abstract}

Keywords: Nonsuicidal self-injury, self-concept, self-criticism, adolescents, bullying victimization.

\section{ABSTRAK}

Nonsuicidal self-injury (NSSI) merupakan tindakan destruktif diri berupa perusakan jaringan tubuh yang langsung, di sengaja dan tanpa intensi bunuh diri. Berbagai penelitian menemukan bahwa perilaku NSSI lebih banyak dilakukan oleh remaja dan dipicu oleh perundungan. Meskipun demikian, belum banyak penelitian yang menjelaskan proses berpikir korban perundungan mengenai dirinya sampai melakukan tindakan NSSI. Penelitian ini bertujuan untuk mengetahui peranan kritik diri sebagai moderator pada hubungan antara konsep diri dan perilaku nonsuicidal selfinjury pada remaja korban perundungan. Jenis penelitian yang digunakan adalah penelitian kuantitatif deskriptif expost facto dengan bentuk non eksperimental tipe korelasional. Partisipan penelitian adalah remaja korban perundungan berusia 12-21 tahun ( $\mathrm{n}=68$ ). Teknik Pengambilan sampel yang dipakai dalam penelitian ini adalah convenience non probability sampling. Alat ukur dalam penelitian ini adalah Tennessee Self Concept Scale (TSCS) untuk mengukur konsep diri. Alat ukur Forms of Self-Criticising/Attacking \& Self Reassuring Scale (FSCRS) untuk mengukur kritik diri. Serta alat ukur Inventory of Statement About Self Injury (ISAS) untuk mengukur perilaku NSSI. Penelitian ini menggunakan teknik analisis regresi linier berganda. Hasil dari penelitian ini menunjukkan bahwa kritik diri berperan sebagai mediator sempurna pada hubungan antara konsep diri dan perilaku NSSI remaja korban perundungan. Hasil penelitian juga menunjukkan bahwa konsep diri berkorelasi secara negatif dengan kritik diri dan perilaku NSSI. Artinya, semakin positif konsep diri seseorang maka kritik diri akan menurun dan semakin kecil kemungkinan ia melakukan tindakan NSSI. Hasil penelitian ini sangat penting dalam memahami proses berpikir pelaku NSSI, serta dalam menentukan tindakan preventif yang berfokus pada pengembangan konsep diri dan penurunan kritik diri.

Kata Kunci: Nonsuicidal self-injury, konsep diri, kritik diri, remaja, korban perundungan 


\section{PENDAHULUAN}

\section{Latar Belakang}

Fenomena perilaku melukai diri tanpa intensi bunuh diri (Nonsuicidal Self Injury) telah menjadi hal umum pada anak remaja. Perilaku ini menjadi ancaman serius bagi kesehatan mental, mengingat dampaknya bagi kesehatan fisik maupun psikologis secara jangka panjang. Nonsuicidal Self-Injury (NSSI) didefinisikan sebagai kerusakan jaringan tubuh yang disengaja tanpa intensi bunuh diri, dengan menggores, mengiris, dan mengukir kulit menggunakan benda tajam, memukul atau membenturkan kepala, dan membakar bagian tubuh tertentu (American Psychiatric Association, 2013).

Di Indonesia, fenomena melukai diri menjadi sebuah fenomena gunung es yang menjangkiti kalangan remaja. Dalam waktu yang berdekatan pada tahun 2018, ditemukan sebanyak 56 pelajar SMP di Surabaya, 55 pelajar SMP di Pekanbaru, serta 41 pelajar SMP di Gunung Sugih, Lampung Tengah menyayat tangan menggunakan silet serta benda tajam lain hingga terluka (Hardiansyah, 2018). Selain itu, dalam beberapa penelitian ditemukan bahwa 38\% dari 307 pelajar universitas swasta di Indonesia dan 43,1\% dari 116 pelajar SMA di Yogyakarta pernah melakukan NSSI (Tresno et al., 2012; Kristiani, 2018).

Banyaknya remaja yang mengalami NSSI disebabkan oleh berbagai faktor risiko, namun beberapa penelitian menemukan bahwa perundungan merupakan faktor yang paling kuat (Brunstein Klomek et al., 2016; Lereya et al., 2015; Mossige et al., 2014). Kekerasan, baik secara fisik maupun verbal, maupun pengucilan sosial yang dilakukan oleh teman-teman sebaya, menjadi faktor pemicu munculnya berbagai perilaku melukai diri (Lereya et al, 2015). Menurut hasil riset Programme for International Student Assessment (PISA) 2018, Indonesia menempati urutan ke lima dari 78 negara sebagai negara yang paling banyak murid yang mengalami perundungan (Jayani, 2019). Hasil riset yang dilakukan oleh UNICEF menunjukkan bahwa salah satu dampak dari perundungan yang terjadi secara luas di Indonesia adalah perilaku melukai diri (13\%), terutama bagi perempuan (Kementerian Kesehatan RI, 2018).

Melihat fenomena remaja yang melakukan tindakan NSSI dan perundungan yang meluas di Indonesia, maka memahami proses berpikir pada korban perundungan sampai melakukan tindakan NSSI menjadi sangat penting. Menurut Esposito et al. (2019), penolakan oleh teman sebaya menjadi faktor pendorong korban perundungan untuk melakukan tindakan NSSI. Gilbert dan Irons (2009) mengatakan bahwa penerimaan atau penolakan dari teman sebaya dapat memunculkan konsep diri negatif pada diri individu. Padahal menurut Hooley dan Franklin (2018), penghalang utama bagi individu untuk melakukan tindakan NSSI adalah pandangan yang positif terhadap diri. Menurut Harter (dalam Papalia, 2009), konsep diri merupakan sebuah konstruksi kognitif individu mengenai dirinya, yaitu bagaimana individu melihat dirinya secara keseluruhan, baik kemampuan maupun sifat-sifat yang dimilikinya, yang mendeskripsikan apa yang ia tahu dan rasakan mengenai dirinya dan mengarahkan setiap tindakannya. Sedangkan menurut Fitts (dalam Agustiani, 2009), konsep diri diperoleh dari interaksi individu dengan lingkungannya yang membentuk cara pandang terhadap dirinya. Jika pengalaman interaksi tersebut merupakan sesuatu yang buruk, maka ia akan cenderung menilai dirinya secara negatif, dan sebaliknya. Menurut Hooley dan Franklin (2018) jika seseorang menilai dirinya secara positif, ia akan cenderung melindungi tubuhnya daripada merusaknya secara sengaja.

Kritik diri (self-criticism) merupakan sebuah serangan internal atau inner harassment terhadap diri yang mendatangkan perasaan tidak mampu, terpuruk, dan bahkan membenci diri dan ingin menghukum diri sendiri saat individu mengalami kegagalan atau peristiwa yang buruk (Gilbert, 
2004). Individu yang memiliki kritik diri yang tinggi terbukti memiliki daya tahan diri yang lebih tinggi terhadap rasa sakit, bahkan meningkatkan afek positif (Fox et al., 2017). Kritik diri yang tinggi berupa rasa benci diri (self-hatred) dan rasa jijik terhadap diri (self-disgust) ditambah kepercayaan akan penilaian yang buruk dari orang lain terhadap dirinya menjadi prediktor yang kuat akan tindakan NSSI (Cunha et al., 2017; Gouveia et al., 2016).

Berdasarkan uraian di atas, penelitian ini membangun asumsi bahwa kritik diri memediasi hubungan antara konsep diri dan tindakan NSSI remaja korban perundungan. Berbagai penelitian sudah membuktikan adanya hubungan yang kuat antara perundungan dengan perilaku NSSI (Baiden et al., 2017; Brunstein Klomek et al., 2015; Claes et al., 2015). Penelitian lainnya menemukan bahwa menjadi korban perundungan berhubungan dengan konsep diri negatif (Mishna et al., 2016; Turner et al., 2015). Selain itu, meskipun berbagai penelitian menemukan peran kritik diri pada perilaku NSSI, namun karakteristik partisipannya adalah usia dewasa (Fox et al., 2017; Hooley et al., 2010; Hooley \& St. Germain, 2014), mengalami kekerasan dalam keluarga dan hubungan keluarga yang buruk (Di Pierro, 2012; Glassman, 2007), serta berada dalam perawatan psikiatri (Adrian, 2011; Weismoore, 2010). Dengan demikian, sejauh pengetahuan peneliti, penelitian mengenai peran kritik diri sebagai mediator antara konsep diri dan perilaku NSSI pada remaja korban perundungan belum dilakukan. Oleh karena itu, penelitian ini diharapkan dapat memberikan pemahaman yang lebih mendalam mengenai perilaku NSSI pada remaja korban perundungan ditinjau dari proses kognitifnya.

Penelitian ini bertujuan untuk menjawab permasalahan penelitian bahwa apakah ada peran kritik diri sebagai mediator hubungan antara konsep diri dan tindakan NSSI remaja yang menjadi korban perundungan? Dengan demikian, hipotesis penelitian ini adalah kritik diri (self-criticism) berperan sebagai mediator dalam hubungan antara konsep diri dengan tindakan Nonsuicidal Self-Injury pada remaja korban perundungan.

\section{METODE PENELITIAN}

\section{Partisipan Penelitian}

Partisipan dalam penelitian ini adalah 68 remaja berusia 12-21 tahun yang pernah atau sedang mengalami perundungan. Partisipan mengisi kuesioner secara daring melalui tautan Google form. Partisipan merupakan siswa-siswi SMA di sebuah sekolah di Jakarta dan masyarakat umum. Teknik pengambilan sampel pada penelitian menggunakan teknik convenience nonprobability sampling.

Tabel 1. Profil Demografi dan Pengalaman Perundungan Partisipan $(n=68)$

\begin{tabular}{llll}
\hline Data & & Frekuensi & Persentase \\
\hline Jenis Kelamin & Laki-laki & 24 & 35.3 \\
& Perempuan & 44 & 64.7 \\
Usia & $12-14$ tahun & 3 & 4.4 \\
& $15-17$ tahun & 41 & 60.3 \\
Pendidikan & $18-21$ tahun & 24 & 35.3 \\
& SMP & 3 & 4.4 \\
& SMA/SMK & 45 & 66.2 \\
Jenis Perundungan & Universitas & 19 & 27.9 \\
& Bekerja & 1 & 1.5 \\
& Fisik & 7 & 10.3 \\
& Verbal & 41 & 60.3 \\
Durasi Perundungan & Relasional & 16 & 23.5 \\
& Siber & 4 & 5.9 \\
& 1 bulan & 20 & 29.4
\end{tabular}




\begin{tabular}{llll} 
& 6 bulan & 6 & 8.8 \\
& 1 tahun & 4 & 5.9 \\
Frekuensi Perundungan & Lebih dari 1 tahun & 38 & 59.9 \\
& Sangat Sering & 3 & 4.4 \\
& Sering & 9 & 13.2 \\
& Cukup Sering & 16 & 23.5 \\
& Jarang & 17 & 25 \\
Terakhir Dirundung & Sangat Jarang & 23 & 33.8 \\
& 1 minggu & 2 & 2.9 \\
& 1 bulan & 6 & 8.8 \\
& 6 bulan & 8 & 11.8 \\
& 1 tahun & 6 & 8.8 \\
& Lebih dari 1 tahun & 45 & 66.2 \\
& Tidak ingat & 1 & 1.5 \\
\hline
\end{tabular}

\section{Desain dan Prosedur Penelitian}

Desain yang digunakan dalam penelitian ini adalah kuantitatif deskriptif ex-post facto dengan bentuk non eksperimen. Pengisian kuesioner dilakukan secara daring yang disebarkan melalui tautan Google form yang dibagikan lewat media sosial. Kuesioner terdiri dari lembaran informed consent, data demografis, screening perundungan, serta alat ukur yang mengukur tiga variabel utama yaitu konsep diri, kritik diri dan nonsuicidal self-injury. Pada lembaran informed consent peneliti menjelaskan nama, institusi, tujuan penelitian, jaminan kerahasiaan, permohonan untuk mengisi dengan jujur, serta pernyataan keikutsertaan secara sukarela. Pada lembaran data demografis, partisipan mengisi biografi singkat sebagai data kontrol. Pada lembaran screening perundungan, partisipan mengisi data pengalaman perundungan yang terdiri dari jenis, durasi, frekuensi, terakhir kali dirundung, tempat dirundung dan pelaku perundungan. Pada lembaran alat ukur, peneliti menjelaskan maksud alat ukur secara singkat dan cara pengisian alat ukur.

\section{Alat Ukur Penelitian}

Nonsuicidal Self-Injury (NSSI)

Alat ukur perilaku NSSI yang digunakan dalam penelitian ini adalah The Inventory of Statement About Self Injury (ISAS) yang diterjemahkan ke dalam Bahasa Indonesia atas seijin Catherine R. Glenn selaku corresponding author. ISAS adalah alat ukur self-report yang dikembangkan dengan tujuan mengukur perilaku dan fungsi NSSI. ISAS terdiri dari dua bagian, yaitu bagian I yang mengukur perilaku NSSI dan bagian II yang mengukur fungsi NSSI (Klonsky \& Glenn, 2008). Penelitian ini hanya menggunakan bagian I dari ISAS karena hanya ingin mengukur perilaku NSSI. Bagian I ISAS terdiri dari dua bagian. Bagian pertama mengukur frekuensi 12 perilaku NSSI, yaitu mengiris kulit, menggigit, membakar, mengukir kulit, mencubit dengan keras, menarik rambut, menggaruk dengan keras, memukul atau membenturkan diri, mencegah penyembuhan luka, menggosok kulit pada permukaan kasar, menusuk diri dengan jarum, dan menelan zat berbahaya. Bagian kedua, berupa data deskriptif mengenai usia pertama kali dan terakhir kali melakukan tindakan NSSI, pengalaman mengalami rasa sakit, apakah perilaku NSSI dilakukan sendiri atau dengan kehadiran orang lain, waktu antara desakan keinginan melukai diri sampai tindakan, serta keinginan menghentikan tindakan NSSI. Melalui hasil uji reliabilitas awal diketahui bahwa alat ukur ISAS bagian 1 memiliki koefisien alpha Cronbach sebesar 0.707 yang masuk kategori baik.

\section{Konsep Diri}

Alat ukur Konsep Diri dalam penelitian menggunakan kuesioner Tennessee Self-Concept Scale (TSCS) dari William H. Fitts (1971 dalam Sari, 2012). TSCS terdiri dari 100 butir pernyataan berbentuk skala Likert dengan lima alternatif jawaban sebagai berikut: Sangat Tidak Sesuai, Tidak 
Sesuai, Tidak Pasti, Sesuai, dan Sangat Sesuai. Item nomor 1-51 adalah item-item positif (kecuali item no $15,17,18,34,35,36)$, sedangkan item no 52-100 adalah item negatif sehingga saat melakukan perhitungan skor harus dibalik. Pada penelitian ini, awalnya didapatkan internal consistency alpha Cronbach sebesar 0.928. Setelah butir-butir di bawah 0.2 dibuang didapatkan hasil reliabilitas 0.957 dengan 81 butir yang memenuhi syarat.

\section{Kritik Diri}

Alat ukur kritik diri dalam penelitian ini menggunakan The Forms of Self-Criticising/Attacking \& Self-Reassuring Scale (FSCRS) yang diterjemahkan ke dalam Bahasa Indonesia oleh peneliti atas seijin Prof. Paul Gilbert. The Forms of Self-Criticising/Attacking \& Self-Reassuring Scale (FSCRS) adalah alat ukur yang terdiri dari 22 item yang mengukur konstruk Self-Criticism berjumlah 14 item dan Self-Reassurance berjumlah 8 item. FSCRS berbentuk skala Likert dengan lima alternatif jawaban sebagai berikut: "Sama sekali tidak sesuai dengan saya, sedikit sesuai dengan saya, cukup sesuai dengan saya, sesuai dengan saya, dan sangat sesuai dengan saya." Berdasarkan tujuan penelitian ini, maka yang akan diukur hanya bentuk self criticism, yang terdiri dari Inadequate Self (IS) dan Hated Self (HS). Hasil internal consistency Alpha Cronbach untuk IS adalah .897 dan HS adalah .873 yang menunjukkan butir-butir tersebut memiliki interkorelasi yang tinggi.

\section{Analisa Data}

Metode yang digunakan untuk menganalisa data adalah dengan regresi berganda karena menggunakan variabel mediator. Uji model mediator berdasarkan teori oleh Baron dan Kenny (1986) yang menyatakan bahwa mediasi sempurna (perfect mediator) terjadi jika variabel independen tidak memiliki pengaruh saat variabel mediator dikendalikan. Sedangkan mediasi parsial (partial mediator) terjadi apabila pengaruh variabel independen terhadap variabel dependen menurun namun masih memiliki pengaruh saat variabel mediator dimasukkan. Dengan demikian, peneliti melakukan uji regresi untuk mengetahui peran variabel mediator dalam hubungan antara variabel bebas dan variabel terikat. Data diolah menggunakan program SPSS versi 24.

\section{HASIL DAN PEMBAHASAN}

\section{Hasil}

Jumlah partisipan yang melakukan tindakan NSSI setidaknya sekali dalam rentang 6 bulan terakhir adalah 43 orang (63.2\%), yang terdiri dari laki-laki 15 orang dan perempuan 28 orang.

Berikut gambaran data jenis tindakan dan frekuensi tindakan NSSI.

Tabel 2

Data Jenis Tindakan dan Frekuensi Tindakan Nonsuicidal Self-Injury

\begin{tabular}{lccccc}
\hline \multicolumn{1}{c}{ Jenis tindakan } & Frekuensi & (kali) & \\
& $1-6$ & $7-14$ & $15-24$ & $>25$ & Total \\
\hline Mengiris kulit & 8 & 2 & 1 & 1 & 12 \\
Menggaruk dengan keras & 11 & 5 & 1 & 9 & 26 \\
Menggigit & 16 & 2 & 1 & 3 & 22 \\
Memukul/membenturkan diri & 16 & 7 & 0 & 4 & 27 \\
Menggosok kulit pada permukaan kasar & 9 & 1 & 0 & 0 & 10 \\
Mencubit dengan keras & 20 & 3 & 1 & 3 & 27 \\
Menusuk diri dengan jarum & 5 & 1 & 0 & 0 & 6 \\
Menarik/mencabuti rambut & 13 & 3 & 2 & 4 & 22 \\
Menelan zat berbahaya & 2 & 1 & 0 & 0 & 3 \\
\hline
\end{tabular}




\section{Uji Asumsi}

Uji normalitas data pada 3 variabel penelitian menggunakan metode Kolmogorov-smirnov. Hasil menunjukkan bahwa data bersifat normal dengan nilai Sig. 0.133.

\section{Hasil Uji Regresi}

Uji regresi dilakukan dalam tiga tahap, yaitu: Pertama, Uji peranan Konsep Diri terhadap perilaku NSSI. Hasil analisis data menunjukkan korelasi negatif yang signifikan antara Konsep Diri dengan perilaku NSSI $(\mathrm{t}=-2.037 ; \mathrm{p}=0.046<0.05 ; \beta=-0.243)$. Kedua, Uji peranan Konsep Diri terhadap Kritik Diri. Hasil analisis data menunjukkan korelasi negatif yang signifikan antara Konsep Diri dengan Kritik Diri $t=-6.173 ; p=0.00<0.05 ; \beta=-0.605)$. Ketiga, Uji peranan Kritik Diri sebagai mediator antara Konsep Diri dan perilaku NSSI. Hasil regresi antara kritik diri dan perilaku NSSI menunjukkan korelasi positif yang signifikan antara kritik diri dengan perilaku NSSI $(\mathrm{t}=3.822$; $\mathrm{p}=0.00<0.05 ; \beta=0.522$ ). Kemudian hasil regresi antara konsep diri dan perilaku NSSI menunjukkan skor regresi konsep diri dan perilaku NSSI yang menurun dan menjadi tidak signifikan $(\mathrm{t}=0.530 ; \mathrm{p}=0.598>0.05 ; \beta=0.72$. Nilai tersebut menunjukkan bahwa kritik diri merupakan mediator sempurna (perfect mediator).

\section{Pembahasan}

NSSI merupakan masalah yang serius, lebih banyak dialami oleh remaja, dan sering kali dipicu oleh perundungan. Korban perundungan yang merasa ditolak oleh teman-teman sebayanya dapat memandang diri secara negatif sehingga memengaruhi konsep dirinya. Konsep diri yang negatif dapat memicu munculnya kritik diri, sedangkan seseorang yang memiliki kritik diri yang tinggi dapat lebih mudah menghukum diri lewat tindakan NSSI. Tujuan penelitian ini adalah untuk meneliti peranan kritik diri sebagai mediator hubungan antara konsep diri dengan tindakan nonsuicidal self-injury pada remaja korban perundungan.

Temuan pertama dari penelitian ini adalah adanya korelasi negatif antara Konsep Diri dan tindakan NSSI. Hal ini ini membuktikan bahwa semakin positif konsep diri individu, maka semakin kecil pula kemungkinan ia melakukan tindakan NSSI. Sebaliknya, semakin negatif konsep dirinya, maka semakin besar pula kemungkinannya melakukan tindakan NSSI. Hal ini sesuai dengan model teori yang dikemukakan oleh Hooley dan Franklin (2018) bahwa pandangan yang positif terhadap diri merupakan penghalang utama bagi tindakan NSSI. Individu yang menghargai dirinya, termasuk tubuhnya, tidak akan melukai dan merusaknya secara sengaja dan langsung. Sebaliknya, individu dengan konsep diri negatif lebih mudah untuk percaya bahwa ia memang seseorang yang pantas untuk menerima segala rasa sakit dan lebih siap untuk melakukan tindakan melukai diri lainnya.

Temuan kedua adalah adanya korelasi negatif antara Konsep Diri dan Kritik Diri. Hal ini membuktikan bahwa semakin positif konsep diri individu maka semakin rendah kritik dirinya, sebaliknya semakin negatif konsep dirinya maka semakin tinggi pula kritik dirinya. Hal ini sesuai dengan model teori yang dikemukakan oleh Hooley dan Franklin (2018) yang mengatakan bahwa persepsi negatif tentang diri akan memicu sebuah keyakinan bahwa dirinya memang seseorang yang gagal, tidak mampu, dan pantas untuk dihukum. Gilbert (2006) mengatakan bahwa individu yang mempersepsikan dirinya memiliki hubungan yang positif dengan orang lain akan memiliki skema diri yang positif tentang dirinya, sebaliknya jika individu memiliki hubungan yang negatif dengan orang lain maka ia juga akan memiliki skema diri yang negatif dan lebih rentan untuk mengkritik diri dan menyalahkan diri saat terjadi peristiwa negatif (perundungan). Perundungan yang dipersepsikan sebagai umpan balik negatif dan penolakan dari teman-teman sebaya 
memunculkan skema diri negatif pada diri individu sehingga ia menjadi lebih mudah mengkritik diri, menyerang diri, membenci diri dan menyalahkan dirinya (Gilbert \& Irons, 2009).

Temuan ketiga adalah Kritik Diri sebagai mediator sempurna antara Konsep Diri dan Perilaku NSSI. Hal ini membuktikan bahwa konsep diri yang diperkuat oleh kritik diri berhubungan secara signifikan dengan perilaku NSSI. Hal ini sesuai dengan model teori yang dikemukakan oleh Hooley dan Franklin (2018) yang mengatakan bahwa pandangan negatif tentang diri dapat memunculkan keyakinan bahwa dirinya pantas untuk dihukum dan mengalami rasa sakit yang memotivasinya untuk memilih perilaku NSSI sebagai cara menghukum dirinya. Berkaitan dengan perundungan, menurut Hooley dan Franklin (2018), pengalaman mengalami kegagalan atau mendapat kritikan atau perlakuan buruk dari orang lain dapat menyebabkan persepsi negatif tentang diri sehingga memunculkan cara berpikir dimana melukai diri menjadi lebih memungkinkan dan diinginkan. Melihat kondisi partisipan yang merupakan korban perundungan, maka terbukti bahwa remaja korban perundungan yang memiliki konsep diri negatif dan diperkuat oleh kritik diri yang tinggi memiliki kecenderungan kuat untuk melakukan tindakan NSSI.

\section{KESIMPULAN DAN SARAN \\ Simpulan}

Berdasarkan analisis data, maka hipotesis dari penelitian ini (H1) diterima, yaitu kritik diri berperan sebagai mediator sempurna dalam hubungan antara konsep diri dengan perilaku Nonsuicidal self-injury pada remaja korban perundungan.

\section{Saran}

Berdasarkan hasil penelitian ini, saran praktis yang dapat diberikan untuk orang tua dan pihak sekolah adalah memberikan edukasi mengenai dampak perundungan, terutama terkait dengan tindakan NSSI. Sekolah perlu mengadakan program yang dapat meningkatkan konsep diri para remaja agar tidak sampai memiliki kritik diri yang tinggi, yang dapat memicu tindakan NSSI. Sedangkan saran untuk penelitian selanjutnya adalah dengan menjadikan perundungan sebagai variabel. Hal ini dilakukan untuk memahami lebih jelas dinamika hubungan antara perundungan, konsep diri, kritik diri dan perilaku NSSI. Selain itu, mengingat kelemahan dari penelitian ini adalah menggunakan teknik analisis regresi berganda berdasarkan teori Baron dan Kenny (1986) yang merupakan model lama, maka penelitian selanjutnya dapat menggunakan teknik analisa yang terbaru.

\section{Ucapan Terima Kasih (Acknowledgement)}

Kami ingin mengucapkan terima kasih sebesar-besarnya kepada beberapa pihak yang mendukung proses penelitian ini. Prof. Paul Gilbert yang mengijinkan peneliti menerjemahkan dan menggunakan alat ukur FSCRS; Jaskaran Basran yang mewakili Prof Gilbert dalam memberikan saran dan umpan balik pada proses penerjemahan FSCRS; Prof. Catherine R. Glenn yang mengijinkan peneliti menerjemahkan dan menggunakan alat ukur ISAS; para siswa sekolah M dan remaja lain yang bersedia menjadi partisipan penelitian; para dosen yang memberikan sumbangsih saran dan kritik membangun, yaitu Bpk. Tommy Suyasa, Bpk Eric Wijaya, Ibu Rismiyati E. Koesma dan Ibu Haryanti Satyadi; Ibu I sebagai pimpinan dan Bpk. M sebagai Ka SMA M di Jakarta Utara yang memberikan izin menyebarkan instrumen penelitian pada siswa-siswanya. 


\section{REFERENSI}

Adrian, M., Zeman, J., Erdley, C., Lisa, L., \& Sim, L. (2011). Emotional dysregulation and interpersonal difficulties as risk factors for nonsuicidal self-injury in adolescent girls. Journal of Abnormal Child Psychology, 39(3), 389-400. https://doi.org/10.1007/s10802010-9465-3

Agustiani, H. (2009). Psikologi perkembangan: Pendekatan ekologi kaitannya dengan konsep diri dan penyesuaian diri pada remaja. Refika Aditama.

American Psychiatric Association. (2013). Diagnostic and statistical manual of mental disorder edition "DSM-5". American Psychiatric Publishing.

Baiden, P., Stewart, S. L., \& Fallon, B. (2017). The mediating effect of depressive symptoms on the relationship between bullying victimization and non-suicidal self-injury among adolescents: Findings from community and inpatient mental health settings in Ontario, Canada. Psychiatry Research, 255, 238247. https://doi.org/10.1016/j.psychres.2017.05.018

Baron, R. M., \& Kenny, D. A. (1986). The moderator-mediator variable distinction in social psychological research: Conceptual, strategic, and statistical considerations. Journal of Personality and Social Psychology, 51(6), 1173-1182. https://doi.org/10.1037/00223514.51.6.1173

Brunstein Klomek, A. et al. (2016). Association between victimization by bullying and direct self injurious behavior among adolescence in Europe: a ten-country study. European Child \& Adolescent Psychiatry, 25(11), 1183-1193. https://doi.org/10.1007/s00787-016-0840-7

Claes, L., Luyckx, K., Baetens, I., Van de Ven, M., \& Witteman, C. (2015). Bullying and victimization, depressive mood, and non-suicidal self-injury in adolescents: The moderating role of parental support. Journal of Child and Family Studies, 24(11), 33633371. https://doi.org/10.1007/s10826-015-0138-2

Cunha, P. M., Jose, A. X., \& Dinis, A. (2017). Longitudinal pathways for the maintenance of nonsuicidal self-injury in adolescence: The pernicious blend of depressive symptoms and selfcriticism. Child Youth Care Forum. https://doi.org/10.1007/s 10566-017-9406-1

Di Pierro, R., Sarno, I., Perego, S., Gallucci, M., \& Madeddu, F. (2012). Adolescent nonsuicidal self-injury: The effects of personality traits, family relationships and maltreatment on the presence and severity of behaviours. European Child \& Adolescent Psychiatry, 21(9), 511520. https://doi.org/10.1007/s00787-012-0289-2

Esposito, C., Bacchini, D., Affuso, G. (2019). Adolescent non-suicidal self-injury and its relationships with school bullying and peer rejection. Psychiatry Research, 274, 1-6. https://doi.org/10.1016/j.psychres.2019.02.018

Fox, K. R., Toole, K. E., Franklin, J. C., \& Hooley, J. M. (2017). Why does nonsuicidal self-injury improve mood? A preliminary test of three hypotheses. Clinical Psychological Science, 5(1), 111-121. https://doi.org/10.1177/2167702616662270

Gilbert, P., Clarke, M., Hempel, S., Miles, J. N. V., \& Irons, C. (2004). Criticizing and reassuring oneself: An exploration of forms, styles and reasons in female students. British Journal of Clinical Psychology, 43(1), 31-50. https://doi.org/10.1348/014466504772812959

Gilbert, P., Baldwin, M. W., Irons, C., Baccus, J. R., \& Palmer, M. (2006). Self-criticism and selfwarmth: An imagery study exploring their relation to depression. Journal of Cognitive Psychotherapy, 20(2), 183-200. https://psycnet.apa.org/doi/10.1891/jcop.20.2.183

Gilbert, P., \& Irons, C. (2009). Shame, self-criticism, and self-compassion in adolescence. Adolescent Emotional Development and the Emergence of Depressive Disorders, 195-214. https://doi.org/10.1017/cbo9780511551963.011 
Glassman, L. H., Weierich, M. R., Hooley, J. M., Deliberto, T. L., \& Nock, M. K. (2007). Child maltreatment, non-suicidal self-injury, and the mediating role of self-criticism. Behaviour Research and Therapy, 45(10), 2483-2490. https://doi.org/10.1016/j.brat.2007.04.002

Glenn, C. R., \& Klonsky, E. D. (2011). One-year test-retest reliability of the inventory of statements about self-injury (ISAS). Assessment, 18(3), 375-378. https://doi.org/10.1177/1073191111411669

Gouveia, P., Cunha, M., \& Jose, A. X. (2016). Non-suicidal self-injury in adolescence: The role of shame, self-criticism and fear of self compassion. Child Youth Care Forum. https://doi.org/10.1007/s10566-016-9346-1

Hardiansyah, R. (2018). Sebulan, 152 siswa SMP sayat tangan, para murid mengaku buat penuhi tantangan. TribunLampung.co.id. https://lampung.tribunnews.com/2018/10/05/152-siswasmp-sayat-tangan-dalam-sebulan-para-murid-mengaku-buat-penuhi-tantangan

Hooley, J. M., Ho, D. T., Slater, J., \& Lockshin, A. (2010). Pain perception and nonsuicidal selfinjury: A laboratory investigation. Personality Disorders: Theory, Research, and Treatment, 1(3), 170-179. https://doi.org/10.1037/a0020106

Hooley, J. M., \& St. Germain, S. A. (2013). Nonsuicidal self-injury, pain, and self-criticism. Clinical Psychological Science, 2(3), 297-305. https://doi.org/10.1177/2167702613509372

Hooley, J. M., \& Franklin, J. C. (2018). Why do people hurt themselves ? A new conceptual model of nonsuicidal self-injury. Clinical Psychological Science, 6(3), 428-451. https://doi.org/10.1177/2167702617745641

Jayani, D. H. (2019). PISA: Murid korban "bully" di Indonesia tertinggi ke lima di dunia. https://databoks.katadata.co.id/datapublish/2019/12/12/pisa-murid-korban-bully-diindonesia-tertinggi-kelima-didunia\#: :text=Data\%20hasi1\%20riset\%20Programme\%20for,Indonesia\%20sebanyak\%2 $041 \% 2 \mathrm{C} 1 \% 25$.\&text=Selain $\% 20$ mengalami\%20perundungan $\% 2 \mathrm{C} \% 20$ murid $\% 20 \mathrm{di}, 22 \%$ 25\%20dihina\%20dan\%20barangnya\%20dicuri

Kementrian Kesehatan Republik Indonesia (2018). Kekerasan terhadap anak dan remaja. Depkes.go.id.

http://www.depkes.go.id/download.php?file=download/pusdatin/infodatin/Kekerasanterhadap-anak.pdf

Kristianti, D. A. (2018). Hubungan antara depresi dengan pencederaan terhadap diri sendiri tanpa bunuh diri/non-suicidal self-injury (NSSI) pada siswa SMA di Yogyakarta (Tesis, Fakultas Psikologi Universitas Gadjah Mada). http://etd.repository.ugm.ac.id/

Lereya, S. T., Copeland, W. E., Costello, E. J., \& Wolke, D. (2015). Adult mental health consequences of peer bullying and maltreatment in childhood: Two cohorts in two countries. The Lancet Psychiatry, 2(6), 524-531. https://doi.org/10.1016/S22150366(15)00165-0

Mishna, F., Khoury-Kassabri, M., Schwan, K., Wiener, J., Craig, W., Beran, T., Pepler, D., \& Daciuk, J. (2016). The contribution of social support to children and adolescents' selfperception: The mediating role of bullying victimization. Children and Youth Services Review, 63, 120-127. https://doi.org/10.1016/j.childyouth.2016.02.013

Mossige, S., Huang, L., Straiton, M., \& Roen, K. (2016). Suicidal ideation and self-harm among youths in Norway: Associations with verbal, physical and sexual abuse. Child and Family Social Work, 21(2), 166-175. https://doi.org/10.1111/cfs.12126

Papalia, D. E., Olds, S.W., \& Feldman, R. D. (2009). Human development. McGraw-Hill.

Sari, Y. I. W. (2012). Program pengembangan konsep diri sebagai suatu intervensi untuk meningkatkan kepuasan karyawan dalam upaya mencegah turnover pada perusahaan media X [Thesis, Fakultas Psikologi Universitas Indonesia]. 
Tresno, F., Ito, Y., \& Mearns, J. (2012). Self-injurious behavior and suicide attempts among $\begin{array}{lllll}\text { Indonesian } \quad \text { college } & \text { students. } & \text { Death }\end{array}$ https://doi.org/10.1080/07481187.2011.604464.

Turner, H. A., Shattuck, A., Finkelhor, D., \& Hamby, S. (2016). Effects of poly-victimization on adolescent social support, self-concept, and psychological distress. Journal of Interpersonal Violence, 32(5), 755-780. https://doi.org/10.1177/0886260515586376

Weismoore, J. T., \& Esposito-Smythers, C. (2010). The role of cognitive distortion in the relationship between abuse, assault, and non-suicidal self-injury. J Youth Adolescence. 39, 281-290. https://doi.org/10.1007/s10964-009-9452-6 